\begin{tabular}{|c|c|}
\hline 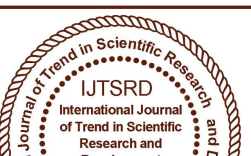 & $\begin{array}{l}\text { International Journal of Trend in Scientific Research and Development (IJTSRD) } \\
\text { International Open Access Journal | www.ijtsrd.com }\end{array}$ \\
\hline a & No: 2456 - 6470 | Volume - 3 | Issue - 1 | Nov - Dec 2018 \\
\hline
\end{tabular}

\title{
Physical, Mechanical and Chemical Characterization on Ancient Brick Masonry of Monuments, Bagan, Myanmar
}

\author{
Thet Mon San, Kyaw Kyaw, Nyan Myint Kyaw \\ Department of Civil Engineering, Yangon Technological University, Yangon, Myanmar
}

\section{ABSTRACT}

Bagan, the Cultural Heritage City of Myanmar, was mainly composed of brick masonry monuments. Some monuments were stone masonry. All of these monuments are vulnerable to both disaster and natural degradation. In order to make proper conservation and repairing work, it is important to know the properties of ancient materials. Therefore, the physical properties and EDX analysis of the ancient bricks from different monuments of $11 \mathrm{AD}, 12 \mathrm{AD}, 13 \mathrm{AD}$ and $18 \mathrm{AD}$ were investigated. Due to the limited amount of samples, ancient mortar from monuments of $13 \mathrm{AD}$, and $18 \mathrm{AD}$ were investigated. It is important to use the similar materials in conservation and repairing work of ancient monuments so that the physical properties and chemical characterization of the new brick from the modern brick mill near Bagan was also performed. Then, the physical properties (unit weight, water absorption) and mechanical properties (compressive strength, flexural strength) of ancient bricks were experimented in the laboratory. Energy-dispersive X-ray EDX analytical technique was performed for the chemical characterization of the ancient brick and mortar samples. In addition, the acid digestion test of ancient lime mortar was conducted in order to know the binder to aggregate ratio. From the evaluation of the physical properties results, ancient bricks were in good range of water absorption. The compressive strength of the ancient bricks were various due to the location of the sample, but most of them have high compressive strength. The chemical characterization results showed that the composition of the ancient bricks and modern bricks were similar but not identical. It was found that the bricks have preserved their originality against environmental and atmospheric affect and their mechanical properties showed that they were produced by appropriate technique.

\section{KEY WORDS: Physical properties, Chemical characterization, EDX analysis, Ancient materials}

\section{INTRODUCTION}

The ancient monuments in Bagan have decayed and deteriorated due to ages, poor maintenance and manmade affect. The final stage of degradation is collapse in which a structure falls in a state where it cannot stay independently falls is a state where it cannot stay independently standing or cannot support applied stress and it loses the equilibrium so that it collapsed or is destroyed. Other deteriorated conditions are deformation, break, crack, decay (due to physical, chemical, and biochemical action), vegetation, poor drainage, leakage, and other factors. Another problem of the monuments is earthquake risk. In Myanmar, Earthquake frequently occurs and these bring little to severe damage to ancient monuments in Bagan. In 1975, the severe earthquake occurred in Myanmar and it caused the collapse of some monuments. Some restoration and reconstruction were performed on these damaged monuments.

In 2016, August 24 , a powerful 6.8-magnitude earthquake has hit central Myanmar near Chauk, Magway region. Chauk is about $32 \mathrm{~km}$ from Bagan and due to this quake, many monuments in Bagan damaged. The rapid visual screening (RVS) assessment was conducted by Myanmar Engineering Society, Myanmar Earthquake Committee and Yangon Technological University in order to identify the damaged level of monuments. According to the survey results, 50 numbers of monuments were severe damage condition, 36 numbers were moderate damage condition and 124 numbers were lightly damage condition [1]. Most of the damaged parts are the reconstructed part after 1975 earthquake. It was seen that the materials used in the reconstruction works 
were different from ancient ones. The reconstructed brick sizes were smaller than the ancient bricks.

Therefore, for the rehabilitation of the damaged monuments of 2016 post earthquake reconstruction and repair work, the thorough understanding of the materials used in the structure is definitely required. A full understanding of the structural and material characteristics is required in conservation practice [2]. Most of the monuments in Bagan are brick masonry with mud mortar and lime mortar. All the structures except the upper parts and the decorations are heavy and massive [3]. The purpose of this study is to get appropriate technical scientific information of the ancient brick and mortar in order to use the compliable materials in rehabilitation of monuments. Therefore, the investigation of old bricks in chemical and physical character was conducted in this study. Moreover, the same investigation was performed on the modern bricks for the conservation and rehabilitation work.

\section{HISTORICAL BACKGROUND}

In 638 A.D, the Pyu, which are Tibeto-Burman, founded the first big Buddhist capital of Burma, Sri Ksetra [4]. The last Sri Ksetra king died in 718 A.D [4]. Sometime later, it seems, the city fell; and the Pyu fell back on Upper Burma, making their new capital Hanlin, 10 miles south of Shwebo [4]. In 850, it is said, the Burmans, Mranma built the wall of Bagan then the advance center, rather than the capital of Tambadipa, the first kingdom of the Burmans in the Central Burma [4]. Compared to the fertile Kharuin areas, Kyaukse and Minbu, Bagan is "the parched country", Tattadesa, of Old Mon / inscriptions [4].Apart from the strange eroded ravines above Naung-U, Bagan is just a sandy windswept plain, strewn with bright pebbles and fossil wood, and sparsely shadowed by low, straining, thorny trees: euphorbia, osyris, jujube, cutch and beautiful whitebarked acacia[4].A few big trees, tamarind and Indian elm and bombax, tower magnificent where there is subsoil water; also the toddy-palm, Palmyra; and some of the humbler plants flower prettily enough, but are too dry for fodder[4]. Bagan, erstwhile capital of Burma (1044-1287 A.D), is situated on the bend in the Ayeyarwady river which flows from the northern hilly regions of the country down to the Andaman Sea [5]. The history of Bagan stated in Academic text books date the first kingdom of Burma from 1044-1334 A.D. the kings were 13, beginning from Aniruddha to Sawnit. The list of the order and reign dates of the kings is ; Anawrahta (1044-1077), Saw Lu (10771084), Kyansittha (1084-1113), Along Sithu (11131160), Narathu (1160-1165), Narapati Sithu (11651211), Nadaung Mya (1211-1230), Naratheinga Uzana (1230-1235), Kyaswa (1235-1249), Uzana (1249-1256), Narathihapate (1256-1287). The interregnum period (1287-1334) was governed by Kyawswa (1287-1298) and Sawnit (1298-1334). However the list of early and legendary monarchs of Burma is still in conflicts. The chief material glory of the Bagan period is its architecture [4]. Most of the monuments, built nearly all of bricks, still stud over 25 square miles which we call Bagan.

\section{STRUCTURAL TYPOLOGY OF BAGAN MONUMENTS}

According to chronicles, in the fifteenth century, King Mohnyin ordered his people to count the number of monuments in Bagan and found their number exceed 4000. Numerous books and articles in Myanmar as well as other countries have been published on Bagan architecture. Most of these have limited number of monuments especially on famous and live monuments. However, Inventory of Monuments at Bagan (Pichard, 1992), published by UNESCO in eight volumes, has been the important basic source for the structural typological classification of Bagan monuments. According to this inventory, there are four main types of structure: temple, stupa, monastery and mound.

Temples are the common typology in Bagan. Based on plan configuration, temples can be classified as (1) temple with central shrine, (2) temple with solid core and (3) temple with central shrine and corridor. Based on Elevation, temples can be classified as (1) Single story temple (2) double or multi stories temple and (3) temple with continuous or discontinuous solid core. Stupas can be divided according to their plan configurations. Monasteries are one to two story monasteries. Most of the monuments were constructed in burnt clay masonry with mud or lime mortar. In some monuments, stone is used to reinforce the arch, wall and base but it is very limited. Reinforced concrete and steel member elements have been used for the 1975 post earthquake reconstructions and repairs of monuments. Physical, mechanical and chemical characterization of ancient bricks for selected temple type monument, stupa type monument, and monastery are shown in Figs. (1),(2), and (3) respectively. 
The ancient brick sizes vary from monuments by monuments. Even in the same monument, the brick sizes are different from the purpose of usage. The average bricks sizes range from $29 \times 16 \times 3 \mathrm{~cm}$ to 40 $\mathrm{x} 18 \times 4 \mathrm{~cm}$. some of the bricks have concave surface at the base and plain surface at the top. The depth of the curve varied from 2.5 to $3 \mathrm{~cm}$. Nowadays, the common brick size varies from $20 \times 10 \times 7 \mathrm{~cm}$ to $22 \times$ $11 \times 8 \mathrm{~cm}$. Although the bread and width of the modern brick is smaller than ancient bricks, the depth of the brick is greater than the old ones. The ancient and modern bricks are shown in Fig.4.
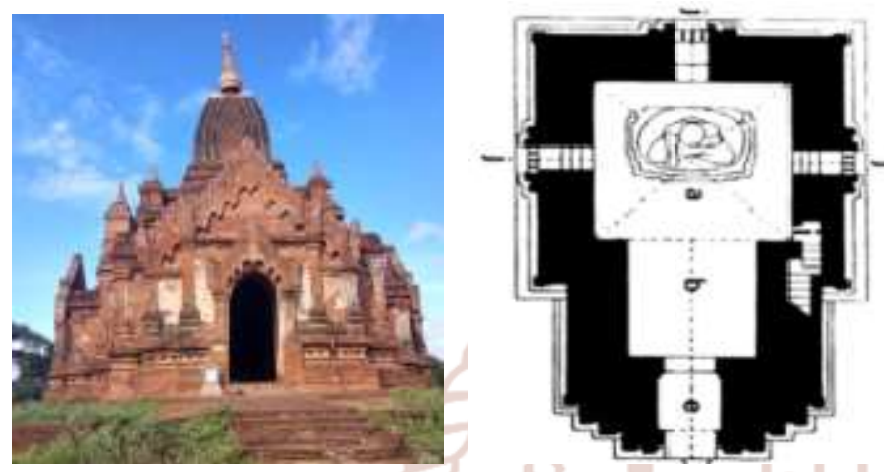

Figure.1.Temple type monument with central

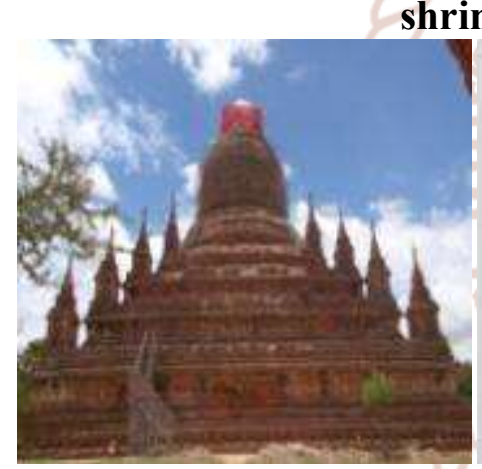

Figure.2. Stupa Type Monument

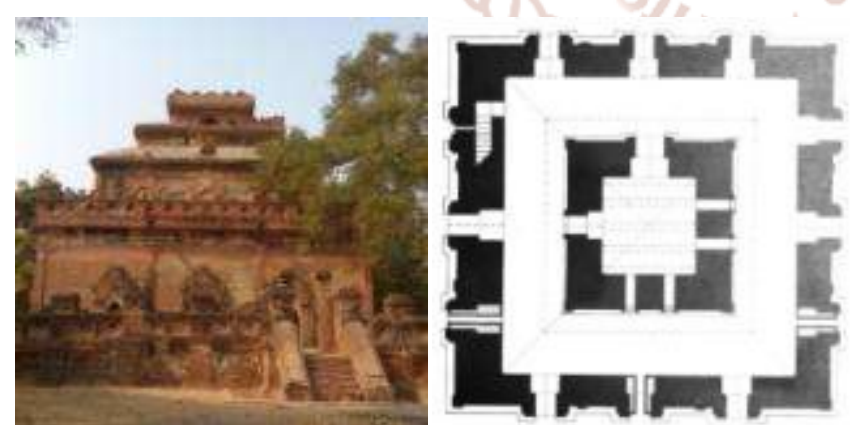

Figure.3. Monastery type Monument Figure.4. (a) Modern Brick and (b) Ancient Brick

\section{SCIENTIFIC INVESTIGATION ANCIENT BRICKS}

\section{A. Sampling of Bricks}

The brick samples were collected from damaged temples, stupas and monastery. The name and construction period of the monuments are described in
Table.1. The collected ancient brick samples of monuments are located in Fig.5. Moreover, the new bricks from modern brick mill were collected in order to make the comparison of ancient and new bricks. The physical properties such as shape, size, color and density of the ancient bricks and modern bricks were studied. The mechanical properties of bricks such as crush test, flexural test and absorption test were experimented according to ASTM standards.

\begin{tabular}{|c|c|c|c|}
\hline No & $\begin{array}{l}\text { Monument } \\
\text { name }\end{array}$ & $\begin{array}{l}\text { Constru } \\
\text { cted } \\
\text { period }\end{array}$ & Sample description \\
\hline 1 & $\begin{array}{l}\text { Abae } \\
\text { Yadanar } \\
\text { (AY) }\end{array}$ & $11 \mathrm{AD}$ & $\begin{array}{l}\text { Only one brick of } \\
\text { full size (ancient } \\
\text { brick) }\end{array}$ \\
\hline 2 & $\begin{array}{l}\text { Ananda- } \\
\text { Ok-Kyaung } \\
(\text { AOK) }\end{array}$ & $\begin{array}{l}(1776- \\
1785)\end{array}$ & $\begin{array}{l}\text { broken bricks (some } \\
\text { are more than the } \\
\text { half size of actual } \\
\text { brick size of } \\
\text { monastery) (ancient } \\
\text { brick) }\end{array}$ \\
\hline 3 & $\begin{array}{l}\text { Mingalar } \\
\text { Zedi } \\
\text { (MGL) } \\
\text { and } \\
\text { ent }\end{array}$ & $\begin{array}{l}13 \mathrm{AD} \\
0 \\
0 \\
0\end{array}$ & $\begin{array}{l}\text { Broken brick under } \\
\text { the ground which are } \\
\text { larger than the half o } \\
\text { the original } \\
\text { size(definitely } \\
\text { ancient brick) }\end{array}$ \\
\hline 4 & $\begin{array}{l}\text { MyayPon } \\
\text { TharPhayar } \\
\text { Hla } \\
\text { (MPT) }\end{array}$ & $12 \mathrm{AD}$ & $\begin{array}{l}\text { full size bricks } \\
\text { appropriate for tests } \\
\text { (not certain ancient } \\
\text { or new brick) }\end{array}$ \\
\hline 5 & $\begin{array}{l}\text { Pu Htoe } \\
\text { Thar Myar } \\
\text { (PHTM) }\end{array}$ & $13 \mathrm{AD}$ & $\begin{array}{l}\text { Full size bricks } \\
\text { appropriate for tests } \\
\text { (ancient brick) }\end{array}$ \\
\hline 6 & $\begin{array}{l}\text { Pyat Sa } \\
\text { Shwe Gu } \\
\text { (PSSG) }\end{array}$ & $12 \mathrm{AD}$ & $\begin{array}{l}\text { Half size brick } \\
\text { appropriate for test } \\
\text { (ancient brick) }\end{array}$ \\
\hline 7 & $\begin{array}{l}\text { SatanarGyi } \\
\text { (STG) }\end{array}$ & $13 \mathrm{AD}$ & $\begin{array}{l}\text { Full size and half } \\
\text { size of bricks free } \\
\text { from cracks (ancient } \\
\text { brick) }\end{array}$ \\
\hline 8 & $\begin{array}{l}\text { Sulamani } \\
\text { (SLMN) }\end{array}$ & $13 \mathrm{AD}$ & $\begin{array}{l}\text { full size bricks and } \\
\text { half size bricks } \\
\text { appropriate for tests } \\
\text { (ancient brick) }\end{array}$ \\
\hline 9 & $\begin{array}{l}\text { Modern } \\
\text { Brick } \\
\text { (MB) }\end{array}$ & $\begin{array}{l}\text { Currentl } \\
\text { y use }\end{array}$ & $\begin{array}{l}\text { full size bricks } \\
\text { appropriate for tests } \\
\text { (new brick from } \\
\text { mail) }\end{array}$ \\
\hline
\end{tabular}




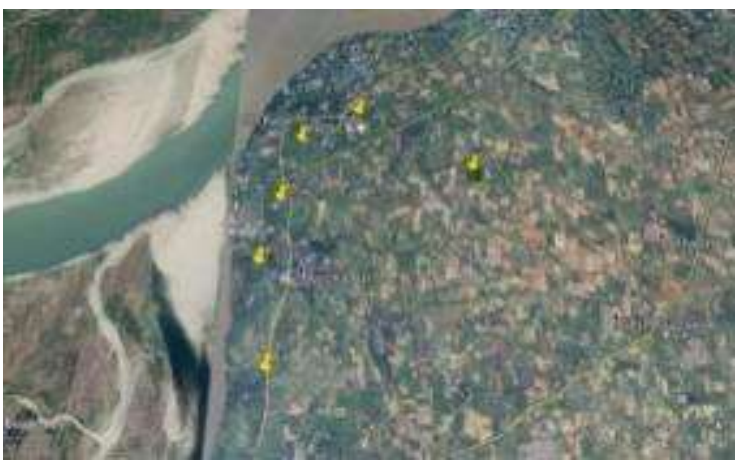

Figure.5. Location of Brick samples

\section{B. Laboratory Tests}

The most important thing for successful conservation work is having adequate knowledge of traditional ancient materials. Therefore, the physical properties such as shape, size, color and density of the ancient bricks were studied. Ancient bricks and modern bricks are tested according to ASTM standards for crash test, flexural test and absorption test. For the quantitative chemical composition of bricks, Energy Dispersive XRay fluorescence (EDXRF) analysis was used.

\section{Physical and Mechanical Properties of Bricks}

From the crush test, the compressive strengths of the collected bricks are as shown Fig. 6. The range of the compressive strength varies from 339 psi to 2078psi. This can be seen that the compressive strength of ancient bricks is much higher than that of modern brick except from the result of Myaypon Thar Phayar Hla's brick which is not certain whether ancient brick or reconstructed brick. The brick form Mingalar Zedi has the highest value because it is the original ancient brick. The flexural strength of ancient bricks was as good as nowadays bricks although they were subjected to weather affects and aging affects. The absorption rate of ancient brick was better than that of modern bricks. The comparison results are shown in Fig. 7 and Fig.8.

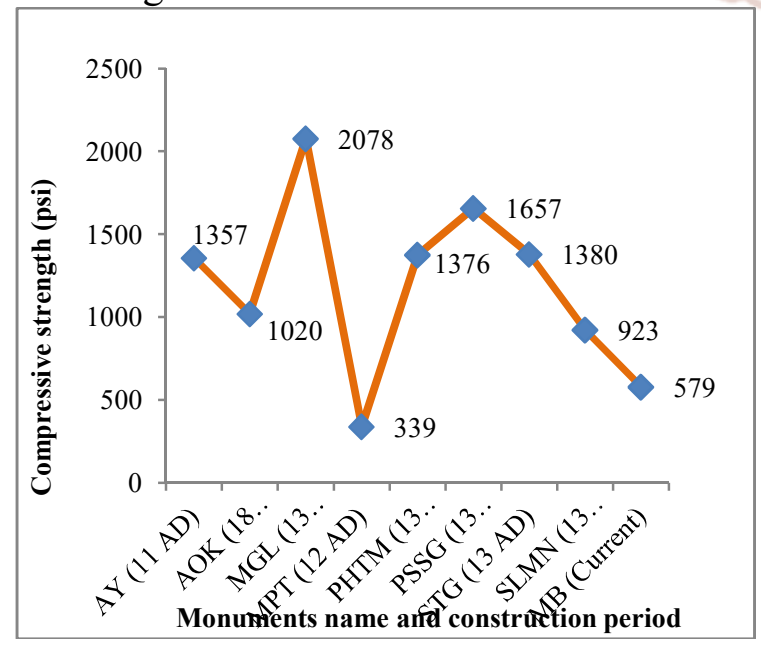

Figure.6 Compressive Strength of Brick Samples

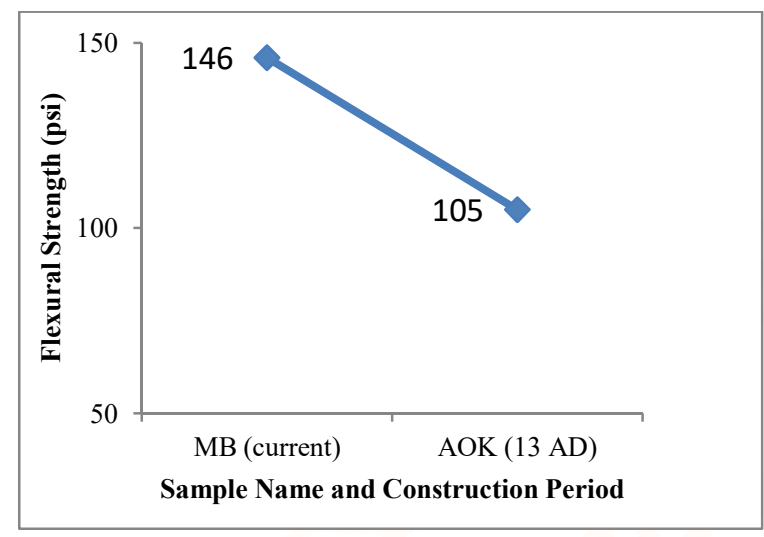

Figure.7 Flexural Strength of Ancient and Modern Bricks

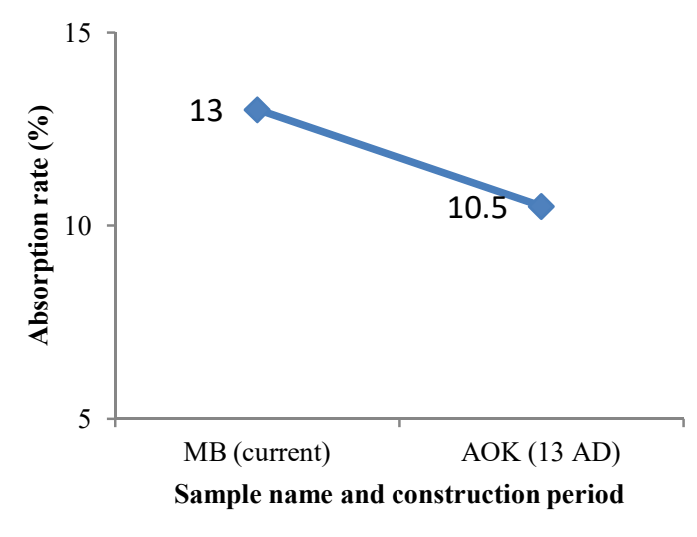

Figure.8 Absorption rate of Ancient and Modern Bricks

The various unit weights of the bricks are shown in Fig.9. the unit weight of ancient bricks varies from $94 \mathrm{lb} / \mathrm{ft}^{3}$ to $121 \mathrm{lb} / \mathrm{ft}^{3}$.

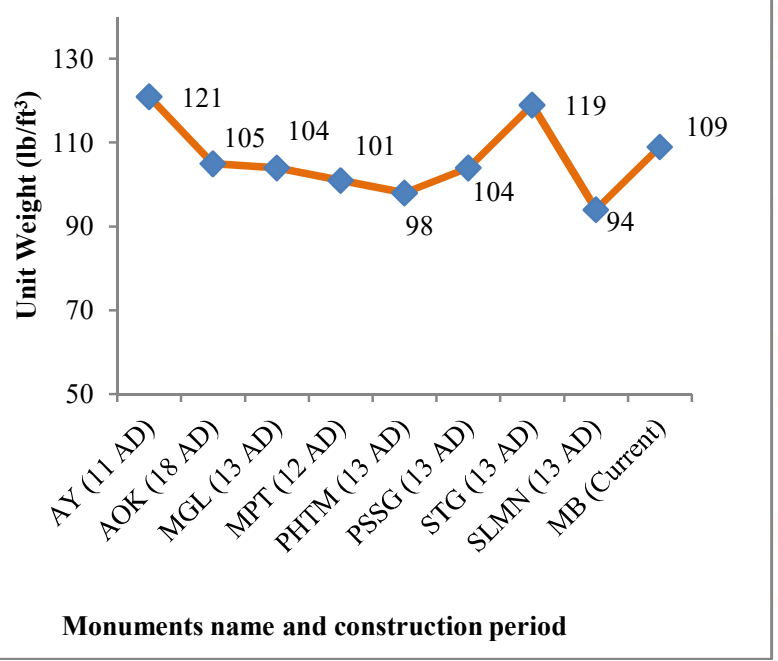

Figure.9 Unit weight of Brick samples

D. Chemical Properties of Bricks

In order to know the quantitative results of chemical composition of brick, EDXRF test is performed on the 
bricks. The results of most of bricks showed very high amount of silicon dioxide followed by aluminum oxide, iron III oxide and potassium oxide. The other compounds compound such as calcium oxide, titanium oxide, manganese oxide, chromium oxide vanadium $\mathrm{V}$ oxide, zirconium oxide, nickel oxide and strontium oxide are found as minor composition less than one percent. The EDXRF results of selected monuments are presented in Fig.10. It can be seen that the $\mathrm{SiO}_{2}$ Content of modern brick is higher than that of ancient bricks and $\mathrm{Al}_{2} \mathrm{O}_{3}$ content of modern brick is lower than that of ancient bricks.

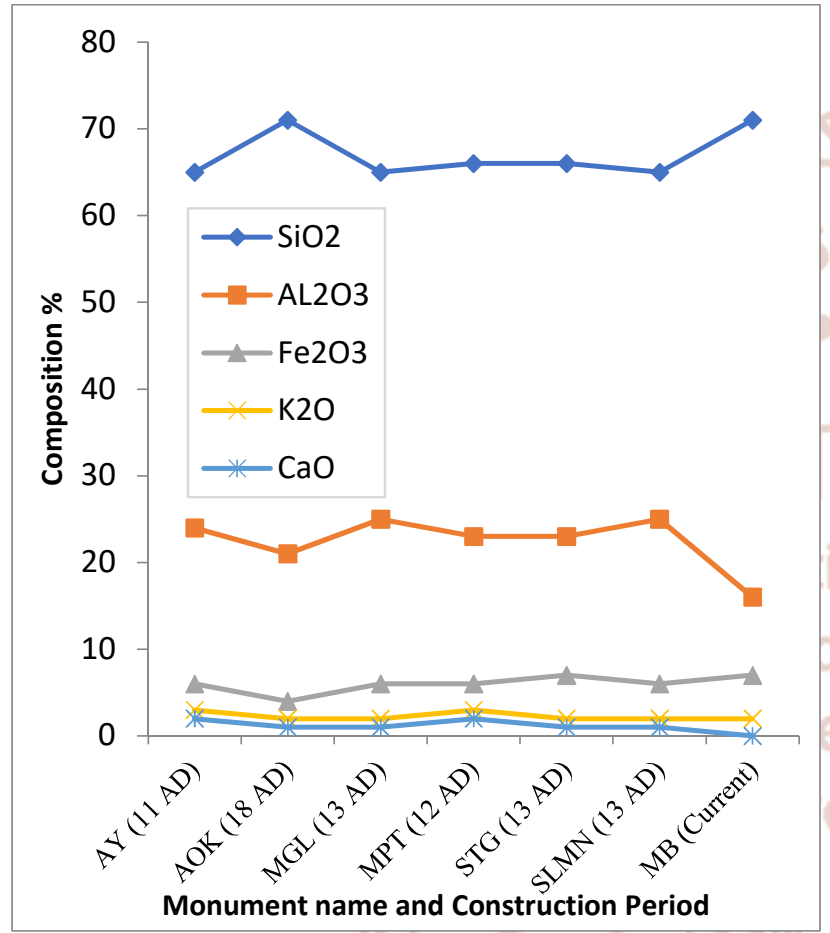

Figure.10 Chemical Composition Ancient and Modern Bricks

\section{SCIENTIFIC INVESTIGATION} ANCIENT MORTAR

\section{A. Sampling of Mortar}

The following mortar samples are collected form the damage monuments. Some new materials from intervention work were seen during the collection of ancient lime mortar. However, the samples for testing are carefully selected to be ancient ones. The sample list of mortar collected form monuments are shown in Table 2.

TABLE.2 SAMPLE LIST OF MORTAR

\begin{tabular}{|c|c|c|c|}
\hline $\begin{array}{c}\mathbf{N} \\
\text { 0. }\end{array}$ & $\begin{array}{c}\text { Monument } \\
\text { name }\end{array}$ & $\begin{array}{c}\text { Constructed } \\
\text { period }\end{array}$ & $\begin{array}{c}\text { Sample } \\
\text { description }\end{array}$ \\
\hline 1 & $\begin{array}{c}\text { Sulamani } \\
\text { (SLMN) }\end{array}$ & 13 AD & $\begin{array}{c}\text { Ancient mortar } \\
\text { form plaster work }\end{array}$ \\
\hline 2 & $\begin{array}{c}\text { Ananda- } \\
\text { Ok-Kyaung } \\
\text { (AOK) }\end{array}$ & $(1776-1785)$ & $\begin{array}{c}\text { Ancient mortar } \\
\text { form plaster work }\end{array}$ \\
\hline
\end{tabular}

\section{B. Chemical Properties of Mortar}

It is difficult to find out the physical properties of ancient mortar in laboratory due to the limited amount of sample. EDXRF test was performed on the ancient mortars for quantitative constituents. Morphological observation and chemical microanalysis were carried out with ZEISS Auriga Modular Crossbeam workstation (FE-SEM) field emission scanning electron microscope equipped with (Oxford) Energy Dispersive Spectrometer (EDS), in order to identify sample constitutive chemical elements. Then, to find out the volumetric proportion of binder to aggregate ratio, acid digestion test was carried out on these two mortar samples. The EDXRF result of lime plaster from Anan-da-ok-kyaung showed the highest amount of Calcium oxide followed by sulphur trioxide, iron III oxide and potassium oxide. The quantitative results of compounds are shown in Table 3. The EDX result of lime plaster from Sulamani showed the highest amount of silicon dioxide followed by aluminum oxide, calcium oxide, iron III oxide and Sulphurtrioxide.

TABLE.3 CHEMICAL COMPOSITION OF
MORTAR
\begin{tabular}{|c|c|c|}
\hline Compounds & $\begin{array}{c}\text { Composition \% of mortar } \\
\text { AOK }\end{array}$ & SLMN \\
\hline & 89 & 9 \\
\hline $\mathrm{CaO}$ & 6 & 1 \\
\hline $\mathrm{SO}_{3}$ & 3 & 1 \\
\hline $47 \mathrm{Fe}_{2} \mathrm{O}_{3}$ & 2 & - \\
\hline $\mathrm{K}_{2} \mathrm{O}$ & 2 & 9 \\
\hline $\mathrm{AL}_{2} \mathrm{O}_{3}$ & - & 21 \\
\hline $\mathrm{SiO}_{2}$ & - & \\
\hline
\end{tabular}

The investigations were carefully carried out on the sample to know the morphology of the surface and the elemental chemical analysis. The SEM image and BSE image of Ananda-Ok-Kyaung is shown in Figure 11. The elemental mapping of some area and 2 EDS microanalysis spots were carried out for chemical constituents. The elemental mapping of area analysis showed the presence of high calcium followed by magnesium, silicon and aluminum. The spots 1 was carried out on a grain and showed that the presence of highest value of calcium, magnesium, silicon and aluminum. The spots 2 was carried out on a dark matrix and showed that the presence of highest value of calcium, magnesium, silicon and aluminum and iron. 


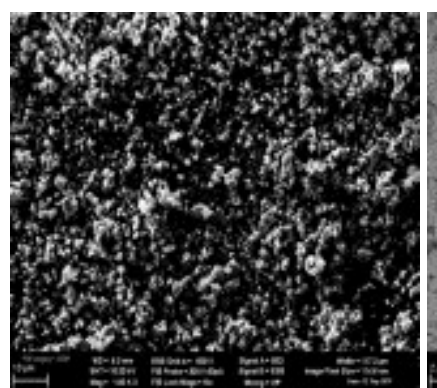

Figure 11 SEM and BSE image of Anan-da-okkyaung

The SEM image and BSE image of the Sulamani Pagoda is shown in Figure 12. The elemental mapping of area analysis showed the presence of high silicon followed by calcium, iron, aluminum, magnesium and feldspar and albite. The spots 1 was carried out on a white color spot and showed that the presence of highest value of calcium, silicon aluminum and magnesium, The spots 2 was carried out on a dark matrix and showed that the presence of highest value of silicon, aluminum, feldspar and calcium and magnesium.

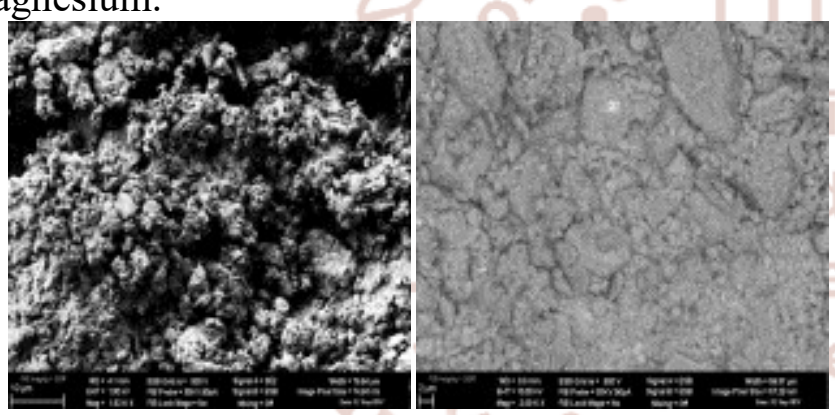

Figure 11 SEM and BSE image of Sula Mani

\section{Acid Digestion Test of Mortar}

Acid digestion test on these two ancient mortars were performed in order to know the binder to aggregate ratio. The binder to aggregate ratio of ancient mortar from two selected monuments are presented in Table4.

TABLE4. BINDER TO AGGREGATE RATIO OF ANCIENT MORTAR

\begin{tabular}{|c|c|c|c|}
\hline $\begin{array}{c}\text { Monume } \\
\text { nt }\end{array}$ & $\begin{array}{c}\text { Location and } \\
\text { appearance }\end{array}$ & $\begin{array}{c}\text { Aggregate } \\
\text { percentage }\end{array}$ & $\begin{array}{c}\text { Binder } \\
\text { percenta } \\
\text { ge }\end{array}$ \\
\hline AOK & $\begin{array}{c}\text { from south } \\
\text { wall of level 1 }\end{array}$ & $68 \%$ & $32 \%$ \\
\hline SLMN & $\begin{array}{c}\text { From the } \\
\text { southern wall }\end{array}$ & $49 \%$ & $51 \%$ \\
\hline
\end{tabular}

\section{DISCUSSION AND CONCLUSION}

In rehabilitation work of heritage monuments, it is important to use the compatible material for structural and architectural point of view. From the RVS assessment results, most of the ancient monuments damaged in secondary structures due to Chauk Earthquake. Another noticeable thing was that most of the renovation works on monuments after 1990 were mostly damaged during 2016 Chauk Earthquake. Total 50 monuments were listed as first priority monuments for immediate action.

From the physical and chemical properties of ancient bricks, the followings conditions are observed. The size, shape, color and texture of modern bricks is quite different from ancient ones. The range of the compressive strength varies from 339psi to 2078psi due to the location and constructed period of the bricks. Some brick contains little amount of husk especially in Anan-da-ok Kyaung. Bricks of two ancient monuments contains $\mathrm{SO}_{3}$ compound in remarkable amount. The texture of these brick is very fine. From the investigation of very fine dust from Bagan area, the dust sample contains a little amount of $\mathrm{SO}_{3}$. According to EDXRF results, clay matrix composition of ancient brick and new brick are quite similar. From the acid digestion test, the binder and aggregate ratio of ancient mortar were observed. For the repair and rehabilitation work of damaged monuments, the brick with proper sizes and compatible strength are definitely required. To sum up, the composition, configuration and production system of the modern bricks and composition of mortar are the key factors for repairing and reconstruction work of damaged monuments in Bagan.

\section{ACKNOWLEDGMENT}

The authors deeply acknowledge to Myanmar Engineering Society. Myanmar Earthquake Committee, (Yangon) and Department of Archeology (Bangan-Nyaung U) are actually indebted for providing rapid visual screening (RVS) data and samples of ancient brick masonry. The author is sincerely thankful to Yangon Technological University for the kindly and valuable supports.

\section{REFERENCES}

1. Myanmar Earthquake Committee, "Rapid visual survey for damages of monuments and buildings due to Chauk Earthquake," Report of Myanmar Earthquake Committee, 2016.

2. "ICOMOS Charter-Principles for the Analysis, Conservation and Structural Restoration of Architectural Heritage," International Council of Monuments and Sites, 2003. 
International Journal of Trend in Scientific Research and Development (IJTSRD) ISSN: 2456-6470

3. J-C Yarmola, "Conservation of Historic Brick Masonry in Pagan," UNDP, UNESCO, 1987.

4. Gordon.H, Luce, "Old Burma: Early Pagan Vol 1," J.J, Augustin Publisher, Locust Valley, New York, 1969.

5. Pierre Pichard, "Inventory of Monuments at Pagan Vol 1 to Vol 8," UNESCO, ISBN 92-3-102795$6,1992.1$

6. "ASTM. Standard test method for sampling and testing bricks and structural clay tile. C67-02, ASTM International," West Conshohocken, United States, 2002.

7. "ASTM. Standard Test Method for Examination and Analysis of Hardened Masonry Mortar. C
1324-03, ASTM International,” West Conshohocken, United States, 2003.

8. "Rapid visual screening of buildings for potential seismic hazards." FEMA 154, Applied Technology Council, Redwood City, California, 2002.

9. ASTM. Standard Test Method for Examination and Analysis of Hardened Masonry Mortar. C 1324-03, ASTM International, West Conshohocken, United States, 2003.

10. Rapid visual screening of buildings for potential seismic hazards. FEMA 154, Applied Technology Council, Redwood City, California, 2002 